\title{
Botanical Composition of Cattle Diets Graz- ing Brush Managed Pastures in East-central Texas
}

\author{
D.R. KIRBY AND J.W. STUTH
}

\begin{abstract}
More grass was consumed in all grazing periods on tebuthiurontreated pastures, and in fall and summer grazing periods on mechanically treated pastures, than on untreated pastures. Cow diets were dominated by grasses, mainly brownseed paspalum and little bluestem, regardless of treatment and season. Similar amounts of forbs were selected from all treatments during all seasons. More woody vegetation was selected from mechanicallytreated and untreated pastures than from tebuthiuron-treated pastures. Forbs decreased and woody vegetation increased in diets from spring through fall. Grasses and leaves decreased, whereas woody vegetation and stems increased in the diets from the beginning to the end of the grazing periods. Within grazing periods forb consumption decreased in fall but increased in summer and spring with time spent in pastures. Small amounts of dead forage were consumed at irregular intervals.
\end{abstract}

Increasing cover of undesirable woody plants is a major problem facing Texas livestock producers. Rangelands comprise about 43 million ha of Texas of which over $88 \%$ are presently so brush infested as to reduce livestock production (Scifres 1980). Solution to most brush problems can best be achieved through a systematic approach of management to brush and grazing.

Following brush management, effective livestock production consistent with good range management depends upon identification of plants selected by grazing livestock. Evaluation of forage consumed by grazing livestock is best accomplished through the use of esophageally fistulated animals (Theurer et al. 1976). Dietary botanical composition has commonly been reported to shift with season (Buchanan et al. 1972, Allison and Kothmann 1979), year (Bohman and Lesperance 1967, Buchanan et al. 1972), and grazing intensity (Galt et al. 1969, Allison and Kothmann 1979).

Information on the effects of brush management on the botanical composition of cattle diets in the Post Oak (Quercus stellata) Savannah of Texas is lacking. This study was initiated to determine the influence of brush management, season, and forage utilization on: (1) the botanical composition of cattle diets, and (2) the preference of cattle for forage classes, and plant species and parts.

\section{Materials and Methods}

Research pastures were located approximately $3 \mathrm{~km}$ southwest of College Station, Texas. Annual average rainfall is $95 \mathrm{~cm}$, with peaks in May and September. Details of climate and vegetation were reported by Kirby (1980). Two replications of three treatments applied in May 1977 and fenced into 1.5 and 2.5-ha pastures included: (1) no treatment, (2) mechanical dozing and piling of \footnotetext{
Authors are former research assistant and assistant professor, Department of
Range Science, Texas Agr. Exp. Sta., Texas A\&M University System, College Station 77843. Kirby is presently assistant professor, Department of Botany, North Dakota State Univ., Fargo 58105.

The authors gratefully acknowledge Dr. C.J. Scifres and Dr. R. Bovey for their assistance in the initiation of this study.

Published with the approval of the Director. Texas Agr. Exp. Sta, as TA-16368.

Received for publication September 18, 1980.
}

underbrush and small trees, and (3) aerially applied, 20\% tebuthiuron pellets at $2.2 \mathrm{~kg} /$ ha (active ingredient).

A seasonal grazing sequence of fall (September to December) 1977, summer (June to September) 1978, and spring (March to June) 1979 was established so that the study pastures would be rested approximately 210 days between grazing periods. An equal number of steers ( 150 to $200 \mathrm{~kg}$ ) were allocated each season to study pastures to properly utilize the available forage within the 90-day seasons. Each seasonal grazing period was terminated at $50 \%$ utilization of the key management herbaceous species, little bluestem in spring and summer, and brownseed paspalum in fall.

Estimates of herbaceous production and availability $(\mathrm{kg} / \mathrm{ha})$ at the beginning and end of each seasonal grazing period were determined by hand-clipping to ground level all vegetation rooted within $15, .25-\mathrm{m}^{2}$ plot frames. In addition, 15 , adjacent paired, $.25-\mathrm{m}^{2}$ plots protected from grazing were clipped seasonally at the termination of grazing periods for determination of forage disappearance. Available browse was not determined due to time constraints imposed by the large diversity and amount of woody species present on the site. Kirby (1980) has described the density of these woody species.

Grass clipped in the field was separated by species. Forbs, including vines, were composited by clipped plot. Clipped forage was weighed in the field and representative amounts of each grass species and all forbs were oven dried at $65^{\circ} \mathrm{C}$ for $72 \mathrm{hr}$. Field weights were then corrected for moisture content and converted to percent composition by weight.

The procedure for dietary collection was previously reported by Kirby and Stuth (1982b). Dietary samples from each cow were thoroughly mixed and a subsample of approximately $1 \mathrm{~kg}$ removed. Subsamples were then composited across animals by brush treatment, and date of collection, and frozen at $-20^{\circ} \mathrm{C}$. These composited samples were lyophilized and stored in plastic bags until determination of botanical composition.

Botanical composition analysis followed the microscopic analysis technique described by Kothmann (1968). Plant fragments were identified within 20 randomly selected micro-plots. Data were recorded by species as leaf or stem, live or dead, and unidentifiable. Derived categories included total grasses, forbs, and woody, and total leaf: stem and live: dead ratios.

Data were analyzed seasonally by analysis of va riance utilizing a randomized complete block design with two replications of each treatment. Duncan's multiple range test was used to compare differences among means (Steel and Torrie 1960).

\section{Results and Discussion}

Grasses dominated the herbaceous composition of study pastures in all seasons particularly in the tebuthiuron-treated pastures (Table 1). Forbs increased in composition on pastures throughout the study. Forb composition was similar in untreated 


\begin{tabular}{|c|c|c|c|c|c|c|c|c|c|c|c|c|c|c|c|c|c|c|}
\hline \multirow[b]{3}{*}{ Species } & \multicolumn{9}{|c|}{ Pasture } & \multicolumn{9}{|c|}{ Diet } \\
\hline & \multicolumn{3}{|c|}{ Spring } & \multicolumn{3}{|c|}{ Summer } & \multicolumn{3}{|c|}{ Fall } & \multicolumn{3}{|c|}{ Spring } & \multicolumn{3}{|c|}{ Summer } & \multicolumn{3}{|c|}{ Fall } \\
\hline & $\mathbf{N}$ & M & $\mathrm{T}$ & $\mathbf{N}$ & $\mathbf{M}$ & $\mathrm{T}$ & $\mathbf{N}$ & $\mathbf{M}$ & $T$ & $\mathbf{N}$ & M & $\mathrm{T}$ & $\mathbf{N}$ & $\mathbf{M}$ & $\mathrm{T}$ & $\mathbf{N}$ & $\mathbf{M}$ & $\mathrm{T}$ \\
\hline \multicolumn{19}{|l|}{ Grass and grasslike } \\
\hline Barnyardgrass (Echinochloa crusgalli) & 0 & $\mathrm{t}^{2}$ & 0 & $\mathrm{t}$ & $\mathrm{t}$ & $\mathrm{t}$ & 1 & 2 & 4 & 0 & 0 & 0 & 0 & 0 & 0 & 0 & 0 & 0 \\
\hline Broomsedge bluestem (Andropogon virginicus) & 0 & 0 & 0 & 0 & 2 & 1 & 3 & 12 & 8 & 0 & 0 & 0 & 0 & 0 & 0 & 1 & 0 & 0 \\
\hline Brownseed paspalum (Paspalum plicatulum) & 22 & 17 & 14 & 33 & 38 & 63 & 48 & 41 & 54 & 28 & 23 & 23 & 40 & 50 & 55 & 41 & 52 & 56 \\
\hline Chasmanthium sp. & $\mathrm{t}$ & 0 & $\mathrm{t}$ & 0 & 0 & 0 & 1 & 0 & $\mathfrak{t}$ & 0 & 0 & 0 & 0 & 0 & 1 & 0 & 0 & 0 \\
\hline Dicanthelium sp. & 2 & 13 & 2 & 1 & 2 & 0 & 3 & 5 & 2 & 2 & 2 & 2 & 0 & 0 & 0 & $\mathrm{t}$ & 1 & 1 \\
\hline Fall witchgrass (Leptoloma cognatum) & 0 & 0 & 0 & 0 & 1 & 0 & 1 & $\mathrm{t}$ & 0 & 0 & 0 & 0 & 0 & 0 & 0 & 0 & 0 & 0 \\
\hline Florida paspalum (Paspalum floridanum) & 1 & 0 & 23 & 3 & 0 & 7 & 0 & $\mathrm{t}$ & 1 & 1 & $\mathrm{t}$ & 11 & 0 & 0 & 6 & $t$ & 1 & 1 \\
\hline Johnsongrass (Sorghum halepense) & 0 & 0 & 0 & 0 & 0 & 0 & 0 & 0 & 0 & 0 & $\mathrm{t}$ & $\mathrm{t}$ & 0 & 0 & $\mathrm{t}$ & $i$ & $\mathrm{t}$ & 0 \\
\hline Little bluestem (Schizachyrium scoparium) & 16 & 11 & 20 & 28 & 15 & 20 & 26 & 12 & 19 & 24 & 25 & 30 & 29 & 26 & 26 & 13 & 12 & 12 \\
\hline Meadow dropseed (Sporobolus asper) & 1 & $\mathrm{t}$ & 0 & 0 & 1 & $\mathrm{t}$ & 0 & 0 & 0 & 0 & 0 & 0 & 0 & 0 & 0 & 0 & 0 & 0 \\
\hline Oldfield threeawn (Aristida oligantha) & 1 & 2 & 3 & 0 & 0 & $t$ & 2 & 1 & $\mathbf{t}$ & 0 & 0 & 0 & 0 & 0 & 0 & 0 & 0 & 0 \\
\hline Red lovegrass (Eragrostis intermedia) & $\mathrm{t}$ & 1 & 0 & $\mathrm{t}$ & 1 & 0 & 0 & 0 & 0 & 0 & 0 & 0 & 0 & 0 & 0 & 0 & 0 & 0 \\
\hline Rushes (Juncus sp.) & 1 & 2 & $\mathrm{t}$ & $\mathrm{t}$ & 1 & $\mathrm{t}$ & 1 & 0 & $\mathrm{t}$ & 0 & 0 & 0 & 0 & 0 & 0 & 0 & 0 & 0 \\
\hline Sedges (Carex sp.) & 12 & 7 & 11 & 4 & 2 & 2 & 4 & 3 & 5 & 1 & 1 & $\mathrm{t}$ & 1 & 1 & 1 & 3 & 1 & 4 \\
\hline Silver bluestem (Bothriochloa saccharoides) & 0 & 0 & 0 & 3 & 0 & 0 & 0 & 6 & $\mathrm{t}$ & 0 & 0 & 0 & 0 & 0 & 0 & 0 & 0 & 0 \\
\hline Texas wintergrass (Stipa leucotricha) & 0 & $\mathrm{t}$ & 0 & $\mathrm{t}$ & 0 & $\mathrm{t}$ & 1 & $\mathrm{t}$ & 0 & 1 & 0 & 0 & 1 & $\mathrm{t}$ & $\mathrm{t}$ & 4 & 3 & 5 \\
\hline Winter bentgrass (Agrostis hiemalis) & 0 & $\mathrm{t}$ & 0 & $\mathrm{t}$ & 0 & 0 & 0 & 0 & $\mathbf{0}$ & 0 & 1 & 1 & 0 & 0 & 0 & 0 & 0 & 0 \\
\hline Wright's threeawn (Aristida wrightii) & 2 & $\mathrm{t}$ & $\mathrm{t}$ & $\mathrm{t}$ & $\mathrm{t}$ & $\mathrm{t}$ & 0 & $\mathrm{t}$ & 0 & 0 & 0 & 0 & 0 & 0 & 0 & 0 & 0 & 0 \\
\hline Unidentified & 0 & 3 & $0^{3}$ & 0 & 1 & 2 & 2 & 1 & 0 & 3 & 7 & 4 & 0 & 2 & 0 & 6 & 10 & 4 \\
\hline Total & $58 \mathrm{a}$ & $56 a$ & $74 b^{3}$ & $72 a$ & $64 a$ & $95 b$ & $92 a$ & $83 b$ & $93 \mathrm{a}$ & $60 a$ & $59 a$ & $71 \mathrm{~b}$ & $71 \mathrm{a}$ & $79 \mathrm{~b}$ & $89 c$ & $69 a$ & $80 \mathrm{~b}$ & $83 b$ \\
\hline
\end{tabular}

Forb

Common poison ivy (Rhus toxicodendron)

Croton sp.

Peppervine (Ampelopsis arborea)

Saw greenbriar (Smilax bona-nox)

Southern dewberry (Rubus trivialus)

Thistle (Cirsium sp.)

Unidentified

Total

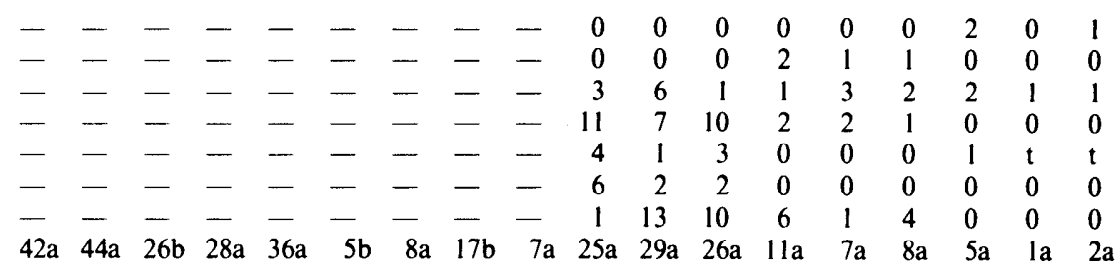

Woody

Oak (Quercus sp.)

Possomhaw yaupon (Ilex decidua)

Willow baccharis (Baccharis salicina)

Winged elm (Ulmus alata)

Yaupon (Ilex vomitoria)

Unidentified

Total

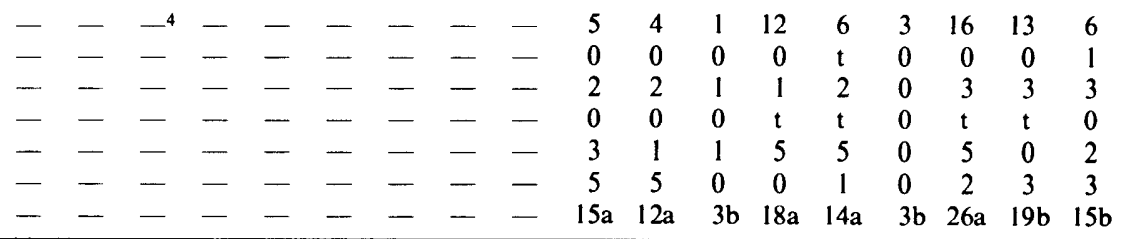

'Brush treatments included: none (N), mechanical (M), and tebuthiuron (T).

Indicates composition of less than $0.5 \%$.

${ }^{3}$ Means within a row and season followed by a different suffix are significantly different $(P<0.05)$

${ }^{4}$ Composition of woody vegetation was not measured in study pastures.

and mechanically treated pastures but was reduced where the herbicide was applied. Of the available herbaceous forages, brownseed paspalum (Paspalum plicatulum) (Gould 1975) and little bluestem (Schizachyrium scoparium) dominated the composition of study pastures. These two grass species jointly comprised $53 \%$ to $83 \%$ of the total herbaceous composition of pastures during the summer and fall grazing periods and averaged $33 \%$ during the spring grazing period. Cow diets selected were dominated by grasses, regardless of season grazed (Table 1). Amounts of brownseed paspalum and little bluestem in cow diets were equal from all pastures during the spring grazing period. However, brownseed paspalum was the major component identified in diets from summer and fall grazing periods. Texas wintergrass (Stipa leucotricha) contributed significantly to fall diets, while Florida paspalum (Paspalum floridanum) increased in diets from tebuthiuron-treated pastures throughout the study.

More grass was consumed $(P \leq 0.05)$ in all seasonal grazing periods on tebuthiuron-treated pastures and in fall and summer on mechanically-treated pastures compared to untreated pastures (Table 1). Similar amounts of forbs were selected from all treatments in seasonal grazing periods. Woody vegetation was consumed less $(P \leq 0.05)$ each successive seasonal grazing period on tebuthiuron-treated pastures when compared to untreated pas- tures. Woody vegetation comprised more $(P \leq 0.05)$ of fall diets on untreated pastures, compared to those from mechanically treated pastures, but was similar to these pastures in spring and summer grazing periods. This indicates that woody resprouts in mechanically treated pastures were consumed no more readily than mature woody vegetation in untreated pastures.

Dietary forb content decreased from spring through fall (Table 2). Vine species, peppervine (Ampelopsis arborea), saw greenbriar (Smilax bona-nox), and southern dewberry (Rubus trivialus) contributed $50 \%$ or more of the forbs identified in diets each season.

As seasons progressed and the availability of desirable forbs declined, cows selected more woody vegetation (Table 1). Oaks (Quercus spp.) contributed most of the woody vegetation in diets during all seasonal grazing periods with yaupons (Ilex spp.) and willow baccharis (Baccharis salicina) being the next most preferred species based on diet composition.

Selection among forage classes varied with time spent in pastures during seasonal grazing periods (Table 2). Selection of grass decreased $(P \leq 0.05)$ and woody selection increased $(P \leq 0.05)$ with time spent in pastures for all seasonal grazing periods. Buchanan et al. (1972) reported the same relationship from diets sampled on a tall forb range in Montana except forbs were substituted for grasses. Forb consumption increased $(P \leq 0.05)$ in spring and 
Table 2. Composition (\%) of cattle diets sampled at the beginning and end of seasonal grazing periods following brush management in east-central Texas. ${ }^{1}$

\begin{tabular}{|c|c|c|c|c|c|c|c|c|c|c|c|c|c|c|c|c|c|c|}
\hline \multirow{3}{*}{$\begin{array}{l}\text { Forage class and } \\
\text { plant part ratios }\end{array}$} & \multicolumn{6}{|c|}{ Spring } & \multicolumn{6}{|c|}{ Summer } & \multicolumn{6}{|c|}{ Fall } \\
\hline & \multicolumn{2}{|r|}{$\mathbf{N}$} & \multicolumn{2}{|r|}{$\mathrm{M}$} & \multicolumn{2}{|r|}{$T$} & \multicolumn{2}{|r|}{$\mathrm{N}$} & \multicolumn{2}{|c|}{$M$} & \multicolumn{2}{|r|}{$\mathrm{T}$} & \multicolumn{2}{|r|}{$\mathbf{N}$} & \multicolumn{2}{|c|}{$\mathbf{M}$} & \multicolumn{2}{|r|}{$T$} \\
\hline & 1 & 2 & 1 & 2 & 1 & 2 & 1 & 2 & 1 & 2 & 1 & 2 & 1 & 2 & 1 & 2 & 1 & 2 \\
\hline Grass & $74 c^{2}$ & $46 b$ & $85 d$ & $32 a$ & 9ld & $53 \mathrm{~b}$ & $81 \mathrm{~d}$ & $61 \mathrm{a}$ & $86 \mathrm{~d}$ & $72 b c$ & $99 \mathrm{e}$ & $79 \mathrm{~cd}$ & $83 d$ & $54 a$ & $92 \mathrm{e}$ & $68 \mathrm{~b}$ & $90 \mathrm{e}$ & $76 c$ \\
\hline leaf:stem & 4.7 & 2.8 & 6.7 & 4.3 & 29.3 & 12.3 & 39.5 & 29.5 & 27.7 & 35.0 & 15.5 & 10.3 & 4.5 & 8.0 & 4.1 & 5.2 & 6.5 & 5.9 \\
\hline live:dead & 7.2 & 8.2 & 41.5 & 15.0 & 44.5 & 25.5 & 80 & -3 & - & - & 98.0 & 78.0 & 41.0 & - & 91.0 & - & 89.0 & 75.0 \\
\hline Forb & $22 b$ & $28 \mathrm{~b}$ & $11 a$ & $47 \mathrm{c}$ & $8 a$ & $43 c$ & $10 \mathrm{~b}$ & $12 b c$ & $0 \mathrm{a}$ & $14 b c$ & $0 \mathrm{a}$ & $16 c$ & $10 c$ & lab & $2 a b$ & 0a & $4 b$ & $l a b$ \\
\hline leaf:stem & 10.0 & 8.3 & 4.5 & 2.6 & - & 6.2 & 9.0 & 11.0 & - & 13.0 & - & 15.0 & 9.0 & - & - & - & - . & - \\
\hline live:dead & 10.0 & 13.0 & 10.0 & - & 3.0 & $\ldots$ & $\ldots$ & $\ldots$ & - & - & - & - & - & & - & - & - & - \\
\hline Woody & $4 \mathrm{a}$ & $26 b$ & $4 a$ & $21 \mathrm{~b}$ & la & $4 a$ & $9 b c$ & $27 \mathrm{~d}$ & $14 c$ & $14 c$ & la & $5 a b$ & $7 a$ & $45 \mathrm{~d}$ & $6 a$ & $32 c$ & $6 a$ & $23 b$ \\
\hline leaf:stem & - & 12.0 & - & 4.3 & - & - & - & 12.5 & 13.0 & - & - & - & - & 21.5 & - & 15.0 & 5.0 & 22.0 \\
\hline live:dead & - & - & - & - & - & $\ldots$ & $\ldots$ & - & - & - & - & 4.0 & - & - & - & - & - & - \\
\hline
\end{tabular}

'Beginning and end sampling dates are represented as $I$ and 2, while brush treatments included: none (N). mechanical (M), and tebuthiuron (T).

'Means within a row and season followed by a different suffix are significantly different $(P<0.05)$.

${ }^{3}$ Either leaf or stem, or live or dead plant parts were absent from diet samples.

summer grazing periods with time spent in pastures. This would indicate that forbs and woody vegetation were not preferred cattle forages in this region of Texas.

In numerous studies, leaves were the major part in livestock diets (Galt et al. 1969, Durham and Kothmann 1977, Allison and Kothmann 1979). All diet samples in this study were also dominated by leaf material (Table 2). Grass and forb stem consumption tended to increase with time spent in pastures especially during dormant periods. This increase in stem consumption was presumably a result of lowered availability in leaf material in the remaining standing crop as grazing intensity increased, and maturation of the vegetation during dormant periods with a subsequent increase in stem portion of available forage. Few woody stems were consumed from the pastures. Dead material was consumed irregularly in very low amounts in each forage class.

Ample availability combined with preference for brownseed paspalum and little bluestem appears to make these two grasses ideal key management species for east-central Texas rangeland used for cattle production. Woody vegetation, whether resprouts or mature, did not appear to be a preferred forage class. Cattle alone should not be expected to maintain or make efficient use of brush infested or mechanically-treated rangeland in this region of Texas. The use of a combination of cattle and goats, that would effectively manipulate the available woody vegetation and maintain the beneficial aspects of mechanical brush management and maximize long-term returns, needs investigation.

\section{Literature Cited}

Allison, C.D., and M.M. Kothmann. 1979. Effect of level of stocking pressure on forage intake and diet quality of range cattle. Proc. West. Sec. Amer. Soc. Anim. Sci. 30:174-178.
Allison, C.D., R.D. Pieper, G.D. Donart, and J.D. Wallace. 1977. Fertilization influences cattle diets on blue grama range during drought. J. Range Manage. 30:177-180.

Bohman, V.R., and A. L. Lesperance. 1967. Methodology research for range forage evaluation. J. Anim. Sci. 26:820-826.

Buchanan, H., W.A. Laycock, and D.A. Price. 1972. Botanical and nutritive content of the summer diet of sheep on a tall forb range in southwestern Montana. J. Anim. Sci. 35:423-430.

Durham, A.J., and M.M. Kothmann. 1977. Forage availability and cattle diets on the Texas Coastal Prairie. J. Range Manage. 30:103-106.

Galt, H.D., C.B. Theurer, J.H. Ehrenreich, W.A. Hale, and S.C. Martin. 1969. Botanical composition of diets of steers grazing a desert grassland range. J. Range Manage. 22:14-19.

Gould, F.W. 1975. Texas plants. A checklist and ecological summary. Texas Agr. Exp. Sta. MP-585.

Kirby, D.R. 1980. Herbaceous response and cattle diets following brush management in the Post Oak Savannah. Ph.D. Diss., Texas A\&M Univ., College Station, Texas.

Kirby, D.R., and J.W. Stuth. 1982b. Brush management influences the nutritive content of cattle diets in east-central Texas. J. Range Manage. 35:431-433.

Kothmann, M.M. 1968. The botanical composition and nutrient content of the diet of sheep grazing poor condition pasture compared to good condition pasture. Ph.D. Diss. Texas A\&M Univ., College Station, Texas.

Scifres, C.J. 1980. Brush Management. Texas A\&M University Press. College Station, Texas.

Steel, R.G.D., and J.H. Torrie. 1960. Principles and Procedures of Statistics. McGraw-Hill, Inc. New York.

Theurer, C.B., A.L. Lesperance, and J.D. Wallace. 1976. Botanical composition of the diet of livestock grazing native ranges. Arizona Agr. Exp. Sta. Tech. Bull. 233. 